\title{
THE INFLUENCE OF TA'LIM MUTA'ALIM UNDERSTANDING TO THE DEVELOPMENT OF SANTRI CHARACTER (Research on Nurussalam Islamic Boarding School Medangasem Jayakerta Karawang)
}

\author{
Khalid Ramdhani \\ khalid.ramdhani@fai.unsika.ac.id \\ University of Singaperbangsa Karawang \\ Laila Ngindana Zulfa, M. Pd. I. \\ lailangindana@unwahas.ac.id \\ University of Wahid Hasyim Semarang
}

\begin{abstract}
ABSTRCT
Ta'lim Muta'alim is a classic book written by Syekh Al Zarnuzi on $593 \mathrm{H}$. As the writer of Ta'lim al-Muta'allim Thariq al-Ta'allum, he emphasizes the aspect of character values physical and spiritual. In this book, education is not only transfer of knowledge and skills, but the most important here is the transfer of character values. The purpose of writing this article is to examine the influence of Talim Muta'alim understanding to santri character development. The research methodology used in this research is based on quantitative approach with path analysis model that explores causality (causal effectual), which analyzes the relationship between Ta'lim Muta'alim understanding variable and santri character at Nurussalam Islamic Modern Boarding School Medangasem Jayakerta Karawang. The results showed that Ta'lim Muta'alim understanding positively and significantly 20,3\% influence the santri's character which suported all of member of boarding school, especially kyai, teachers and santri can run the teachinglearning process.
\end{abstract}

Keyword : Education, Ta'lim Muta'alim, Santri Character.

\section{INTRODUCTION}

Based on preliminary research conducted by researchers at Nurussalam Islamic Modern Boarding School Medangasem Jayakerta Karawang. Apparently found some matters relating to morality among the students at the boarding school. The fact shows the students tend to lie often, sleep in the classroom when the process of learning, say no courtesy to teachers and boarders, lie, late to come to class, not praying 5 time congregation in mosque, fighting between students, santri men disturbing female students, writing and drawing on the wall, the santri senior oppresses the junior santri, walks in the teacher without permission, carrying goods prohibited by boarding school, lawyers, even to immoral acts committed between same sex. From the appearance of some uniformed sons uniformed sons and not put into pants. Long hair and hairstyle that does not reflect as a santri.

This is based on the empirical observations of researchers and interviews with pesantren leaders, to schools, as well as teachers as teachers (ustadz \& ustadzah) at Nurussalam Islamic Boarding School Medangasem Jayakerta Karawang.

The above trends and problems are very important problems to be studied in the world of education, in order to create a superior generation of morals karimah. According to the law of the national education system no: 20 of 2003 on the purpose of education mentioned: 
"The purpose of national education function to develop the ability and embody the character and civilization of dignified nation in the ranks of the nation's intellectual life, aims to improve potential learners to become a faithful and human devout to God Almighty, noble, healthy, knowledgeable, skilled, creative , independent and become a democratic and responsible citizen.

The goal is the hope, wish and ideals of the nation to be achieved in education in Indonesia, to give birth to future generations of noble character. So in this case, boarding school as an educational institution that has contributed greatly to the development of education. By educating students in lahiriyyah and bathiniyyah to make a suitable santri expected by religion, nusa and nation. Not only knowledgeable with broad insight, but more important than that is to create a santri who believe and devoted wholeheartedly with noble morals.

This noble vision is of course applicable in every boarding school. Boarding school has long been an institution forming morality karimah and print nation civilization and meerdaskan life of the nation based on faith and devotion to Allah SWT. As the vision of educational mission initiated by a figure who was born and grow flowers in the area of Al Zarnuji.

Sheikh Al Zarnuji, author of Talim Mutaalim Thariq al Ta'alum emphasized moral values, both on character lahiriyyah and bathiniyyah a claimant of knowledge. In this book, education is not just a transfer of knowledge and skill but most important is the transfer of moral values. The popular book in these pesantrens exposes the concept of education as a whole, not dichotomous, that the morality of a seeker of knowledge is when synergized character lahiriyyah and character bathiniyyah.

According to Al Ghazali in Ihya Ulumuddin (Beirut: 58) that morality can change. If morality does not change, then the testament and education does not mean anything. Moral education according to Al Ghazali can be reached by means of serious (mujahadah) and training (riyadhah) or habituation since childhood continuously. This applies to almost anything, including both bad and good grades. Moral education should be based on religious values, not anti-religion. Because of the general understanding that educators assume that character education is a plus-minded education, which involves knowledge, feelings, and actions and expresses religious values. Character education still leaves a problem.

\section{RESEARCH METHODS}

The research method used is survey method with Regression study approach which is part of correlational quantitative research type. Research by survey method is conducted to know about something phenomenon that happened in society.

This research uses survey research methods with a quantitative approach. According to Kerlinger (Sugiyono, 2014, 12) states that: "Survey research is research conducted on large and small populations, but the data studied are data from samples taken from these populations, to find relative events, distribution, and relationships. -relationships between sociological and psychological variables ".

Furthermore, Lawrence (Sugiyono, 2014,12) explained that "survey research is quantitative research". In survey research, researchers ask several people (called respondents) about beliefs, opinions, characteristics of an object and past or present behavior. Survey research deals with questions about one's own beliefs and behavior. Survey research uses quantitative research in which data obtained from the sample population of the study are then analyzed in accordance with the statistical methods used and then interpreted 
Keerlinger said that survey research is a study conducted on large and small populations, but the power studied is the data and samples taken from the population, so that found the events of relative, distribution and the relationship between sociological and psychological variables. Survey research is usually done to take a generalization and deep observation, but generalization is done more accurately when used a representative sample. So the problem constellation model can be seen from the picture below:

$$
\mathrm{X} \text {--------- > Y }
$$

Information :

$\mathrm{X}$ : Understanding of the Kitab of Ta'lim Muta'alim

Y: character of santri

\section{RESEARCH RESULT}

\section{DESCRIPTIVE ANALYSIS}

Descriptive analysis of each variable studied was done through the help of SPSS version 19. The steps are to activate menu Analyze $=>$ Descriptive $=>$ Statictics $=>$ Frequencies. By default the description obtained is information about Mean, Median, Std Deviation, Minimum Value, Maximum Value.

Table 1.1

Descriptive Analysis of Variable Data

\begin{tabular}{|c|c|c|c|}
\hline \multicolumn{4}{|c|}{ Statistics } \\
\hline & & Understanding & Character \\
\hline \multirow[t]{2}{*}{$\mathrm{N}$} & Valid & 43 & 43 \\
\hline & Missing & 0 & 0 \\
\hline \multicolumn{2}{|c|}{ Mean } & 71.33 & 135.51 \\
\hline \multicolumn{2}{|c|}{ Median } & 71.00 & 136.00 \\
\hline \multicolumn{2}{|c|}{ Mode } & 70 & 131 \\
\hline \multicolumn{2}{|c|}{$\begin{array}{l}\text { Std. } \\
\text { Deviation }\end{array}$} & 5.605 & 10.870 \\
\hline \multicolumn{2}{|c|}{ Variance } & 31.415 & 118.161 \\
\hline \multicolumn{2}{|c|}{ Minimum } & 61 & 108 \\
\hline \multicolumn{2}{|c|}{ Maximum } & 84 & 160 \\
\hline \multicolumn{2}{|c|}{ Sum } & 3067 & 5827 \\
\hline \multicolumn{4}{|c|}{$\begin{array}{l}\text { Multiple model exist. The smallest value is } \\
\text { shown }\end{array}$} \\
\hline
\end{tabular}

The value of the Ta'lim Muta'alim Literary Speech obtained from the respondents has an average of 71.33 , with standard deviation 5,605, median of 71.00 , minimum score 61 and maximum score 84 . 
Tabel 1.2

Talim Muta'alim Understanding Histogram

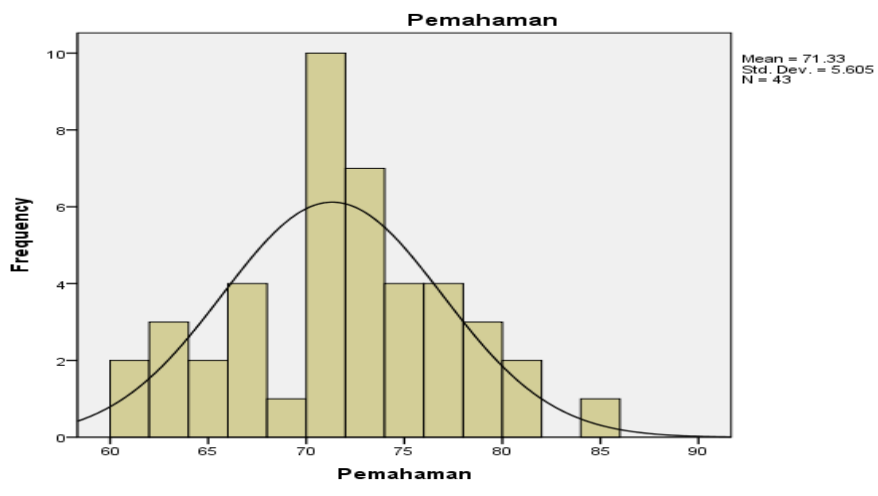

From the distribution table, as well as histogram and polygon frequencies, it can be concluded that the score data of Scientific Understanding Book of Ta'lim Muta'alim Santri in this study has a tendency that normal distribution.

Based on the descriptive table the data of the variables obtained from the respondents had an average of 135.51 and median 136.00, with the standard intersection of 10.870, the minimum score of 108 and the maximum score of 160 . This shows that the observation of santri's morals is very high. The standard deviation score of 10.870 shows the difference of answers among respondents including high. This shows that the morality of students of the various respondents.

From the description it can also be seen that between the mean and median values are almost the same as 135.51 and 136.00. This shows that the score data of moral variable santri in this research enough representative. While the score is above the average more than the below average, indicating that the variable of moral students who are above the average more than the below average. Descriptive data can be seen in the histogram below:

Table 1.3

\section{Santri Character Histogram}

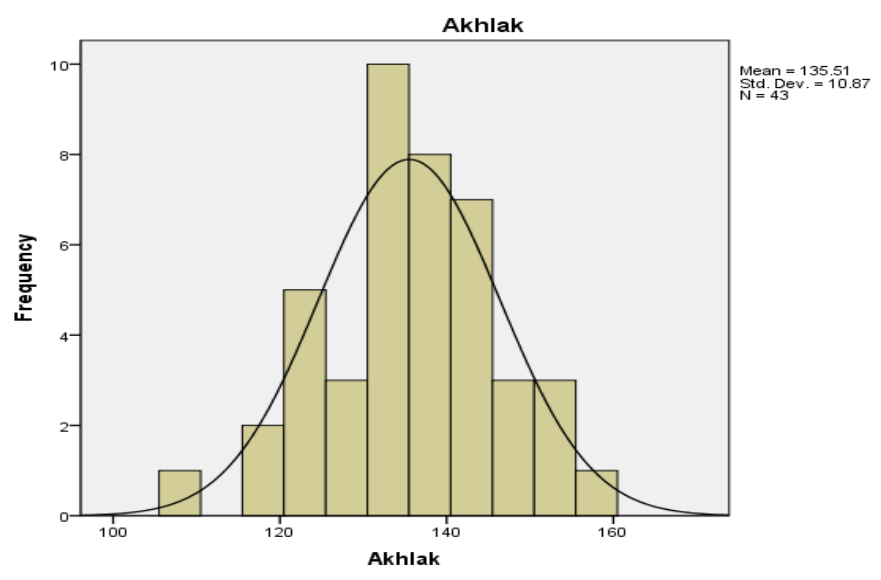

From the distribution table and histogram and polygon frequency above can be concluded that the score data of moral scale santri in this study have the distribution that tend to normal. Testing requirements analysis data which done in this study is the homogeneity normality test and linearity partial line regression between the independent variable and the dependent variable. 
Testing the data normality of each sample is tested through the following hypotheses:

$\mathrm{H} 0$ : the data in the sample is normally distributed

H1: the data in the sample is not normally distributed.

The calculation is done with the help of SPSS 19. According to the provisions of the program, the criteria of data normality are "if p value (sig)> 0.05 then $\mathrm{H} 0$ is received", which means the data in the sample is normally distributed. The p value (sig) is the number shown in the sig cololm in the result / output table calculating the normality test by the SPSS program. In this case the Kolomogorov-Smirnova method is used. The results can be seen in the table below:

Tabel 1.4

Normaliy Data Test

Tests of Normality

\begin{tabular}{|l|r|r|r|r|r|r|}
\hline & \multicolumn{2}{|c|}{ Kolmogorov-Smirnova } & \multicolumn{3}{c|}{ Shapiro-Wilk } \\
\cline { 2 - 7 } & Statistic & \multicolumn{1}{c|}{ df } & \multicolumn{1}{c|}{ Sig. } & Statistic & df & \multicolumn{1}{c|}{ Sig. } \\
\hline Pemahaman & .127 & 43 & .077 & .977 & 43 & .540 \\
Character & .083 & 43 & .200 & .990 & 43 & .966 \\
\hline
\end{tabular}

In the table above shows that the values in the sig column in the Kolomorov-Smirnova method for all samples are greater than 0.05, so $\mathrm{H} 0$ is accepted, in other words that the data of all samples in this study are normalized.

Linearity test in this research used the following hypothesis:

H0: regression line relationship between variable $\mathrm{X}$ and linear $\mathrm{Y}$ variable.

$\mathrm{H} 1$ : regression line relationship between variable $\mathrm{X}$ and variable $\mathrm{Y}$ is not linear.

The calculation is done with the help of computer through SPSS 19 application program. According to the provisions in the program then the criteria of normality of data is "if $p$ value (sig) $<0.05$ then $\mathrm{H} 0$ accepted, which means that the samples come from population homogeny.

The value of $\mathrm{p}$ value ( $\mathrm{sig}$ ) is the number that is teteran in the column of line sig Liniearity in ANOVA table result of linear regression line regression calculation by SPSS program. The result of linearity test calculation of regression line relationship between variable $\mathrm{X}$ with variable Y can be seen in table below:

Table 1.5

Recapitulation of Test Result of LInierity of Line of Relationship Between Variable X with Variable Y

\begin{tabular}{|c|c|c|c|c|c|c|c|}
\hline \multicolumn{8}{|c|}{ ANOVA Table } \\
\hline & & & $\begin{array}{c}\text { Sum of } \\
\text { Squares } \\
\end{array}$ & df & Mean Square & $\mathrm{F}$ & Sig. \\
\hline \multirow{5}{*}{$\begin{array}{l}\text { Character * } \\
\text { Pemahaman }\end{array}$} & Between & (Combined) & 2487.994 & 18 & 138.222 & 1.340 & .248 \\
\hline & Groups & Linearity & 204.020 & 1 & 204.020 & 1.979 & .172 \\
\hline & & $\begin{array}{l}\text { Deviation } \\
\text { from } \\
\text { Linearity }\end{array}$ & 2283.975 & 17 & 134.351 & 1.303 & .270 \\
\hline & Within C & ups & 2474.750 & 24 & 103.115 & & \\
\hline & Total & & 4962.744 & 42 & & & \\
\hline
\end{tabular}


In the table above shows that the value in the column sig line deviation from liniearity = 0.270 for all samples more than 0.05 so $\mathrm{H} 0$ received, in other words that the regression line the relationship between variables $\mathrm{X}$ and linear $\mathrm{Y}$ variables.

Hypothesis testing is done as the provisions written in research methods. The results of calculation and testing can be seen in the table below:

Table 1.6

Results Calculation of Correlation Coefficient Influence Variable X to Variable Y Model Summary

\begin{tabular}{|c|c|c|c|c|c|c|c|c|c|}
\hline \multirow[b]{2}{*}{ Model } & \multirow[b]{2}{*}{$\mathrm{R}$} & \multirow[b]{2}{*}{ R Square } & \multirow[b]{2}{*}{$\begin{array}{l}\text { Adjusted } \\
\text { R Square }\end{array}$} & \multirow[b]{2}{*}{$\begin{array}{l}\text { Std. Error } \\
\text { of the } \\
\text { Estimate }\end{array}$} & \multicolumn{5}{|c|}{ Change Statistics } \\
\hline & & & & & $\begin{array}{c}\mathrm{R} \\
\text { Square } \\
\text { Change }\end{array}$ & $\begin{array}{c}\mathrm{F} \\
\text { Change }\end{array}$ & df1 & df2 & $\begin{array}{c}\text { Sig. F } \\
\text { Change }\end{array}$ \\
\hline 1 & .203 & .041 & .018 & 10.773 & .041 & 1.758 & 1 & 41 & .192 \\
\hline
\end{tabular}

Table 1.7

Recapitulation of Calculation Result of Line Equation of Influence of Variable X to Variable Y

Coefficientsa

\begin{tabular}{|c|c|c|c|c|c|c|c|c|c|c|}
\hline \multirow[b]{2}{*}{ Model } & \multicolumn{2}{|c|}{$\begin{array}{l}\text { Unstandardized } \\
\text { Coefficients }\end{array}$} & \multirow{2}{*}{$\begin{array}{c}\begin{array}{c}\text { Standar } \\
\text { dized } \\
\text { Coeffic } \\
\text { ients }\end{array} \\
\text { Beta }\end{array}$} & \multirow[b]{2}{*}{$\mathrm{T}$} & \multirow[b]{2}{*}{ Sig. } & \multicolumn{3}{|c|}{ Correlations } & \multicolumn{2}{|c|}{$\begin{array}{l}\text { Collinearity } \\
\text { Statistics }\end{array}$} \\
\hline & B & $\begin{array}{l}\text { Std. } \\
\text { Error }\end{array}$ & & & & $\begin{array}{l}\text { Zero- } \\
\text { order }\end{array}$ & $\begin{array}{c}\text { Parti } \\
\text { al }\end{array}$ & Part & $\begin{array}{c}\text { Tolera } \\
\text { nce }\end{array}$ & VIF \\
\hline 1 (Constant) & 107.465 & 21.218 & & $\begin{array}{r}5.06 \\
5\end{array}$ & .000 & & & & & \\
\hline $\begin{array}{l}\text { Understan } \\
\text { ding }\end{array}$ & .393 & .297 & .203 & $\begin{array}{r}1.32 \\
6\end{array}$ & .192 & .203 & .203 & .203 & 1.000 & 1.000 \\
\hline
\end{tabular}

Table 1.8

Recapitulation of Calculation Result Testing The significance of Regression Coefficient Influence of Variable $\mathrm{X}$ on Variable $\mathrm{Y}$

ANOVA

\begin{tabular}{|ll|c|r|r|r|r|}
\hline Model & & $\begin{array}{c}\text { Sum of } \\
\text { Squares }\end{array}$ & Df & $\begin{array}{c}\text { Mean } \\
\text { Square }\end{array}$ & F & Sig. \\
\hline 1 & Regression & 204.020 & 1 & 204.020 & 1.758 & .192 \\
& Residual & 4758.725 & 41 & 116.066 & & \\
& Total & 4962.744 & 42 & & & \\
\hline
\end{tabular}


From the two tables above will be tested one hypothesis namely: the influence of understanding Ta'alim Muta'alim (X) against Character Santri (Y).

The hypothesis of this influence is Ho: $\beta=0 / \mathrm{H} 1: \beta \neq$

Meaning:

Ho: There is no significant influence understanding of Ta'lim Muta'alim (X) on the morality of students (Y).

$\mathrm{H} 1$ : There is a significant influence of the understanding of Ta'lim Muta'alim (X) on the morality of santri (Y).

From the table above shows that the coefficient of double correlation influence free variable understanding of the book Ta'lim Muta'alim santri (X) to santri character (Y) is equal to 0.203 .

From the calculation is obtained that the correlation coefficient is significant, in other words that there is a significant effect of free variables understanding of the book Ta'lim Muta'alim (X) to santri character (Y) is equal to 0.203 .

While the determination coefficient of $20.3 \%$ shows that the amount of the understanding of the understanding of the book of understanding Ta'lim Muta'alim santri (X) against the santri (Y) is $20.3 \%$, the remaining $79.7 \%$ due to other influences.

As for the hypothesis pengjuian through regression analysis obtained calculation results seen in table 1.7. From the table we get the regression line equation which represents the influence of the understanding of Ta'lim Muta'alim santri (X) to santri (Y) is $¥=107,465+0.393$ $\mathrm{X}$. According to the existing criteria, the criterion of significance of the regression is "if sig < 0.05 then Ho is rejected "or if $\mathrm{F}$ arithmetic $>\mathrm{F}$ table then Ho is rejected, which means that the regression coefficient is significant, in other words there is a significant influence free understanding of Ta'lim Muta'alim santri (X) santri character (Y). While the value of $\mathrm{F}$ table is the $\mathrm{F}$ distribution table value for the $5 \%$ real rate with the degree of the numerator $(\mathrm{k})=1$ and the degree of denominator $(n-k-1)=41$ where $n$ is the number of independent variables.

From table 1.7 it shows that the value of $\operatorname{sig}=0,00$ and $\mathrm{F}$ arithmetic $=1,758$. Since the sig $<0,05$ and $F$ arithmetic $>\mathrm{F}$ table then $\mathrm{Ho}$ is accepted which means that the refression coefficient is significant. In other words that there is a significant influence of free variable understanding of the book Ta'lim Muta'alim santri (X) against the dependent variable Character santri (Y).

From the results of testing the correlation and regression it can be concluded that there is influence of the significance of the independent variable understanding of the book Ta'lim Muta'alim santri (X) against the dependent variable Character santri (Y).

This research is to know the influence of the understanding of Ta'lim Muta'alim santri $(\mathrm{X})$ against santri (Y).

From the description of data after correlation analysis obtained correlation coefficient of 1,000 after testing with SPSS program proved that the correlation coefficient is significant. This means that there is influence of the independent variable $(\mathrm{X})$ of the lecture of Ta'lim Muta'alim against (Y) Character Santri.

From regression analysis, the equation of regression line is $¥=107,465+0,393 \mathrm{X}$. Constant value $=107,465$ shows that santri with understanding of Ta'lim Muta'alim santri is difficult to be good, while the value of regression coefficient (tolerance) is 1,000 Dan VIF) 1,000 shows that there is no positive influence of free variable $X$ (understanding of Ta'lim Muta'alim) to variable Y (santri character). After testing the linearity line regression using SPSS program obtained that the regression line is linear. 
From the test of significance of regression coefficient which is also done with SPSS program obtained that regression coefficient is significant, that is indicated by value sig $=0,192$ and $\mathrm{F}$ arithmetic $=1,758$ while $\mathrm{F}$ table $=3.07$ so that sig value $<0,05$ and $\mathrm{F}$ count $>\mathrm{F}$ table or regression is significant which means that there is a positive influence of the independent variable $\mathrm{X}$ on the dependent variable $\mathrm{Y}$.

The results of this study if synergized with the thought of Sheikh al-Zarnuji, author of the book of Ta'lim al-Muta'allim Thariq al-Ta'allum, emphasizing the aspects of moral values, both moral batiniyah and character lahiriyah In this book, education is not just transfer of knowledge knowledge and skills but the most important is the transfer of moral values. The popular book in Indonesian pesantren presents the concept of Islamic education as a whole, not dichotomous. That, the real morality is the synergy between the morality of batiniyah and character lahiriyah. So the santri will have good character. because in this book contained the values that make up individuals who have morals karimah, as discussed from the thirteen chapters which among others are:

1. Explain the nature of science, the law of seeking knowledge, and the virtue of science.

2. Intention in seeking knowledge.

3. How to choose science, teachers, friends, and persistence.

4. How to respect science and teachers.

5. Seriousness in seeking knowledge.

6. Size and order.

7. Tawakal.

8. Study Time Science.

9. Loving each other and exhorting each other.

10. Looking for additional science.

11. Being wara 'when studying.

12. Things that can strengthen memorization and which weaken it.

13. Things that facilitate the arrival of sustenance, things that can prolong and reduce age.

If santri want to have good morality then students should understand the book Ta'lim Muta'alim well so that the students have good morals

From the quantitative and theoretical information, the researcher assumes that there is a positive influence from the understanding of Ta'lim Muta'alim santri to the Santri Character in Nurussalam Islamic Modern Boarding School Medangasem Jayakerta Karawang.

\section{CONCLUSION}

In the conclusion of this section of the authors describe briefly the results of research obtained in the field after the research and data analysis of the Influence of Understanding Book of Ta'lim Muta'alim Santri Against Character Santri can be concluded:

1. There is Influence of Understanding Book of Ta'lim Muta'alim Santri Against Character Santri with fundamental of hypothesis testing obtained that value sig $=0,192$ and $\mathrm{t}$ arithmetic 1.758 while $t$ table 3.07 because sig value $>0,05$ and $\mathrm{T}$ count $<\mathrm{T}$ table then Ho is accepted which means there is a significant effect of free variable $\mathrm{X}$,

2. While the power of donation is shown with the coefficient of determination of $20.3 \%$ which indicates that the contribution of Influence of Understanding Book Ta'lim Muta'alim Santri Against Character Santri 
3. From testing the significance of regression coefficient is also significant that is indicated by the value of sig $=0.000$ and $\mathrm{F}$ arithmetic 1.758 while $\mathrm{F}$ table $=3.07$ so that the sig $<0,05$ and $\mathrm{F}$ arithmetic $>\mathrm{F}$ table or regression is significant, positive variable $\mathrm{X}$ against variable $\mathrm{Y}$.

Thus the understanding of the Book of Muta'alim Santri Ta'lim is very important in determining and improving Character Santri. Based on the findings of the above research that is based on analysis and research, that Santri character can be improved by improving the understanding of the Book of Ta'lim Muta'alim Santri in Nurussalam Islamic Boarding School Medangasem Jayakerta Karawang.

\section{REFERENCE}

Al Ghazali, (2004), Imam, ringkasan ihya' ulumuddin upaya menghidupkan ilmu agama, Surabaya: Bintang Usaha Jaya

Al-Ghazali, Ihya' Ulumuddin, Jilid IV, Beirut-Libanon: Darul Kitab, t.t

Al-Zarnuji, Syekh Ibrahim bin Ismail, Ta'limul Muta'alim, Semarang: CV Toha Putra.As'ad, Aliy Terjemah Ta'limul Muta'allim, Kudus: Menara Kudus, 1995.

Arikunto, S, (2008), Ilmu Pendidikan Teoritis dan Praktis, Yogyakarta : F.P. Yogyakarta.

Arikunto, Suharsimi (1988), Dasar-dasar Evaluasi Pendidikan, Jakarta : Bina Aksara

Lillah, Fathul, Kajian dan Analisis Ta'lim Muta'alim, Sumenag : Santri Salaf Press.

Sudjana, (2002), Metode Statistika, Bandung : Tarsito.

Sudjana, Nana, (2005), Dasar-dasar Proses Belajar Mengajar, Bandung : SInar Baru Algensindo.

Sugiyono. (2014). Metode Penelitian Pendidikan Pendekatan Kuantitatif, Kualitatif, dan R\&D. Bandung: Alfabeta. 